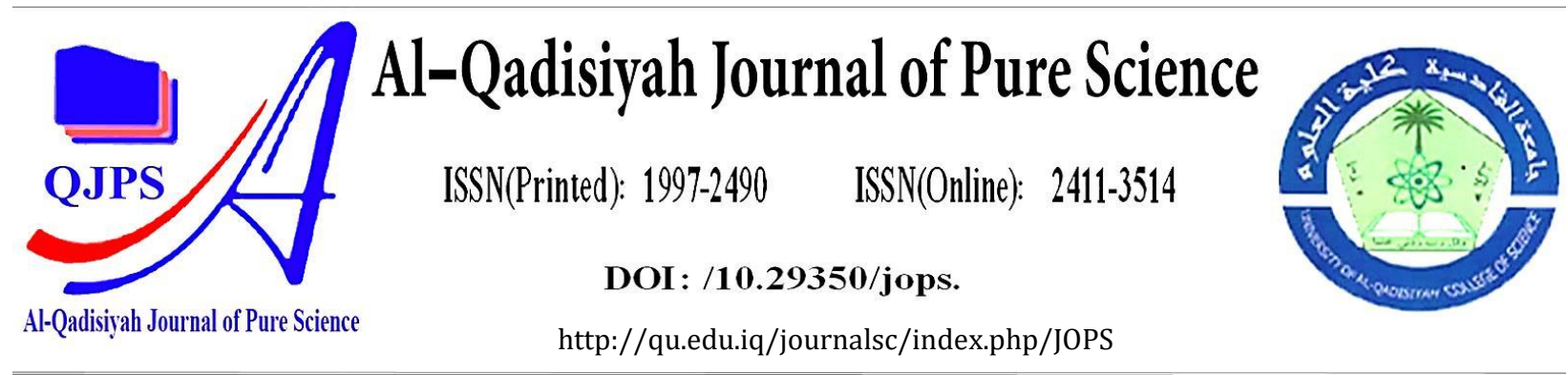

\title{
Biochemical Assessment as Markers for Diagnosis and Evaluation Hepatitis B Virus (HBV)
}

\section{Authors Names \\ a. Moatasem Al-Salih \\ b. Riyad E. Abed \\ c. Syakirah Samsudin \\ Article History}

Received on: 15/6/2021

Revised on: $1 / 7 / 2021$

Accepted on:6/7/2021

Keywords:

Hepatitis B Virus (HBV), Liver Function, Albumin Globulin.

DOI: https://doi.org/10.29350/ jops. 2021.26. 4.1359

\section{ABSTRACT}

Background. Chronic hepatitis B virus (HBV) infection is a major cause of liver morbidity and mortality worldwide. many others risk developing complications of the end-stage liver disease such as decompensated cirrhosis and hepatocellular carcinoma (HCC), without intervention. This study aimed to assess biochemical markers for the development of hepatitis B viruses (HBV), in which any possible connection between certain biochemical parameters and chronic hepatitis was identified. Liver function tests help diagnose liver disease and dysfunction, assess severity, tracking treatment, and determining prognosis. Methods. A total of (200) patients with CHB were admitted to Hepatology and Gastroenterology Teaching Hospital in Baghdad from the first of March to the end of May 2021, aged from 2065 years by mean \pm .SD $31 \mathrm{y}$. The patients were suffering from different clinical symptoms with previous risk factors for transmission of HBV infection. compare with a total of 100 healthy HBs Ag carriers aged from 18-52 years by mean45.06y. According to the findings of biochemical studies, chronic patients have higher levels of ALP, GPT, GOT, and TSB than carriers. The outcome of biochemical tests indicates that the ALP, GPT, GOT and TSB are higher in CHB patients than carrier

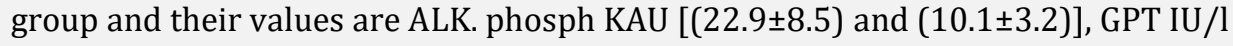
[(45.2 \pm 18.2$)$ and $(13.8 \pm 4.0)]$, GOT IU/l $[(30.6 \pm 11.1)$ and $(13.5 \pm 4.3)]$ and TSB $\mathrm{mg} / \mathrm{dl}[(3.5 \pm 1.9)$ and $(0.9 \pm 0.3)]$ respectively with highly significant difference $(\mathrm{P}<0.001)$ The rise in liver enzymes strongly indicates hepatocellular damage, even though ALP, GPT, GOT, and TSB levels in the carrier group were all within normal parameters as compared to the reference group. Testing liver function in terms of protein level, in conclusion, these findings may cast new light on immune response especially related to deficiencies of liver synthesis of acute-phase proteins and antioxidant enzyme involvement in viral infections and HBV biology. 


\section{Introduction}

Hepatitis is a systemic disease primarily involving the liver as a main target for viral replication which characterized clinically by fever, jaundice and gastrointestinal symptoms $([8,35]$.There is a variety of agents in addition to the viruses that cause liver inflammation (hepatitis) such as bacteria, parasites, fungi and chemical agents including drugs, toxins and alcohol[25, 12].Viral hepatitis is a disease of multiple causes that has been first described in the 5th century B.C when Hippocrates described epidemic jaundice. The recognition a form of hepatitis that has been transmitted by direct inoculation of blood [47, 5] or blood products have been first document by Lurman, Germany in (1883), then the discovery of the etiological agent for hepatitis B and the development of safe and effective vaccines for this virus are among the remarkable scientific achievements of the 20th century [38,22]. Hepatitis B virus (HBV) is a member of the Hepadnavirus family and one of the several unrelated viral species which cause viral hepatitis, the family has been divided into two groups the orthohepadnaviruses were the human HBV belongs to the avian hepadnaviruses. Hepadnaviridae are grouped together with retroviridae and some plant viruses into a superfamily of retroid viruses or reversiviruses. HBV is the smallest human DNA virus and has a very compact genome $[19,58]$.

Hepatitis B virus, consist of an outer lipid envelope and an icosahedral nucleocapsid core, the latter being compose of both protein and DNA [50,49]. The outer envelope contains embedded proteins which are involved in viral binding. Virion shape is generally spherical but polymorphic form exist, including filamentous forms $[27,57,56]$. The DNA genome is not segmented and partially doublestranded containing a long and short segmented which overlap approximately 240 nucleotides to form a closed circle $[52,11]$. The longer strand is 3020-3320 nucleotides long and the shorter is (700-2800) nucleotides (fig: 1) [10, 18].

Hepatitis B virus is structurally complex that it belongs to a group of animal viruses known as hepadnaviridae. It is $42 \mathrm{~nm}$ in diameter and consists of two primary components: a DNA, viral core and an outer protein coat $[50,49]$. The viral core: represents the infectious part of the virus and the outer coat carries the major antigenic determinant of the virus (HBsAg), [6, 59]. The viral core rests within the nucleocapsid of the virus. It is approximately $27 \mathrm{~nm}$ in diameter and contains partially 
double stranded DNA, DNA polymerase, a core antigen (HBcAg) and an 'e 'antigen [28, 39] and fig. (2) shows hepatitis B particle type.

In addition to HBsAg, which accounts for $80 \%$ of the entire surface protein, three other proteins which contain additional polypeptide sequences have been identified. These proteins have been designated pre-S2 and S (middle protein), pre- S1, pre-S2 and S (large protein), and pre-S (small protein) $[53,34,51]$.

Electron microscopy of hepatitis B virus- positive serum has revealed that three morphologically distinct forms of particles:

1. Small $22 \mathrm{~nm}$ spherical or tubular forms comprise of virus surface proteins which are synthesized in excess of the $42 \mathrm{~nm}$ complete virions.

2. Complete $42 \mathrm{~nm}$ virion (Dane particle). The HBsAg differs from the HBsAg found in the $22 \mathrm{~nm}$ particles in that pre- S1 epitopes are present.

3. The $27 \mathrm{~nm}$ nucleocapsid comprises of the DNA genome are surrounded by a second protein, the $\mathrm{HBcAg}$ [39].

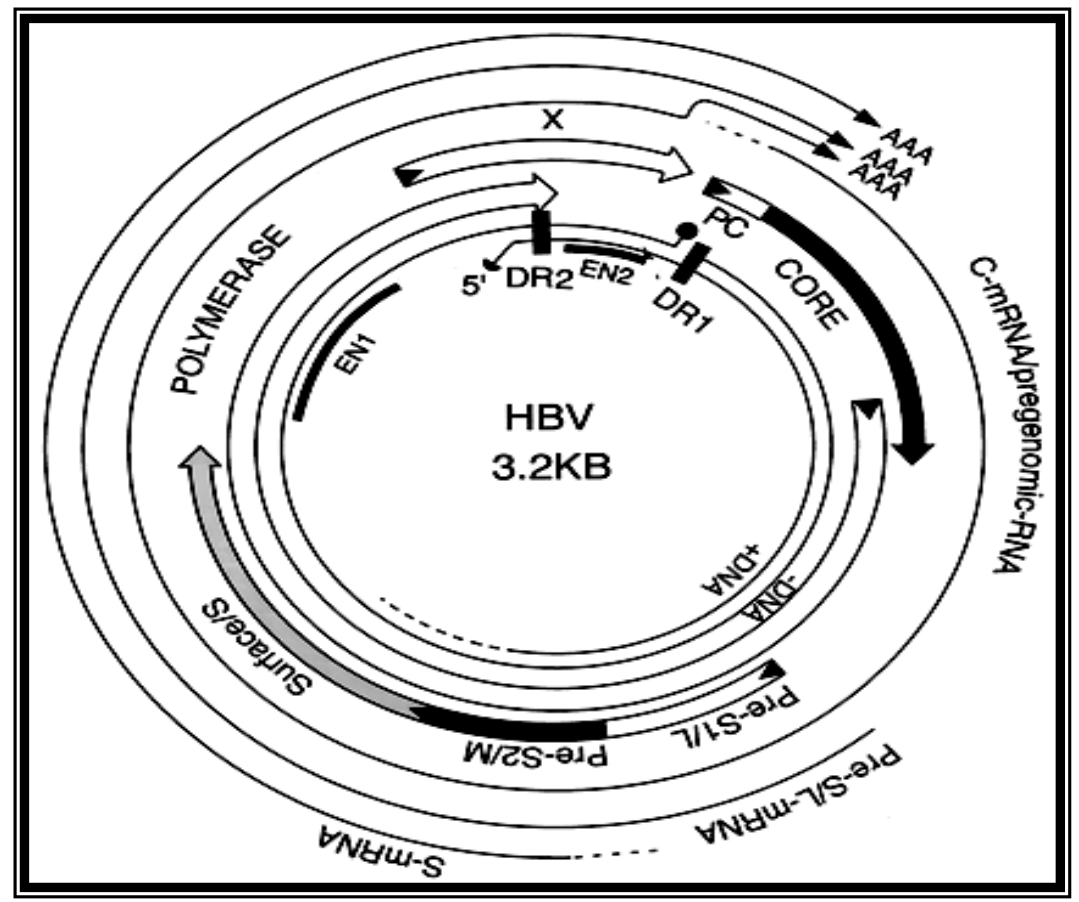

Fig. (1). Schematic representation of the HBV genome [10,18]. 


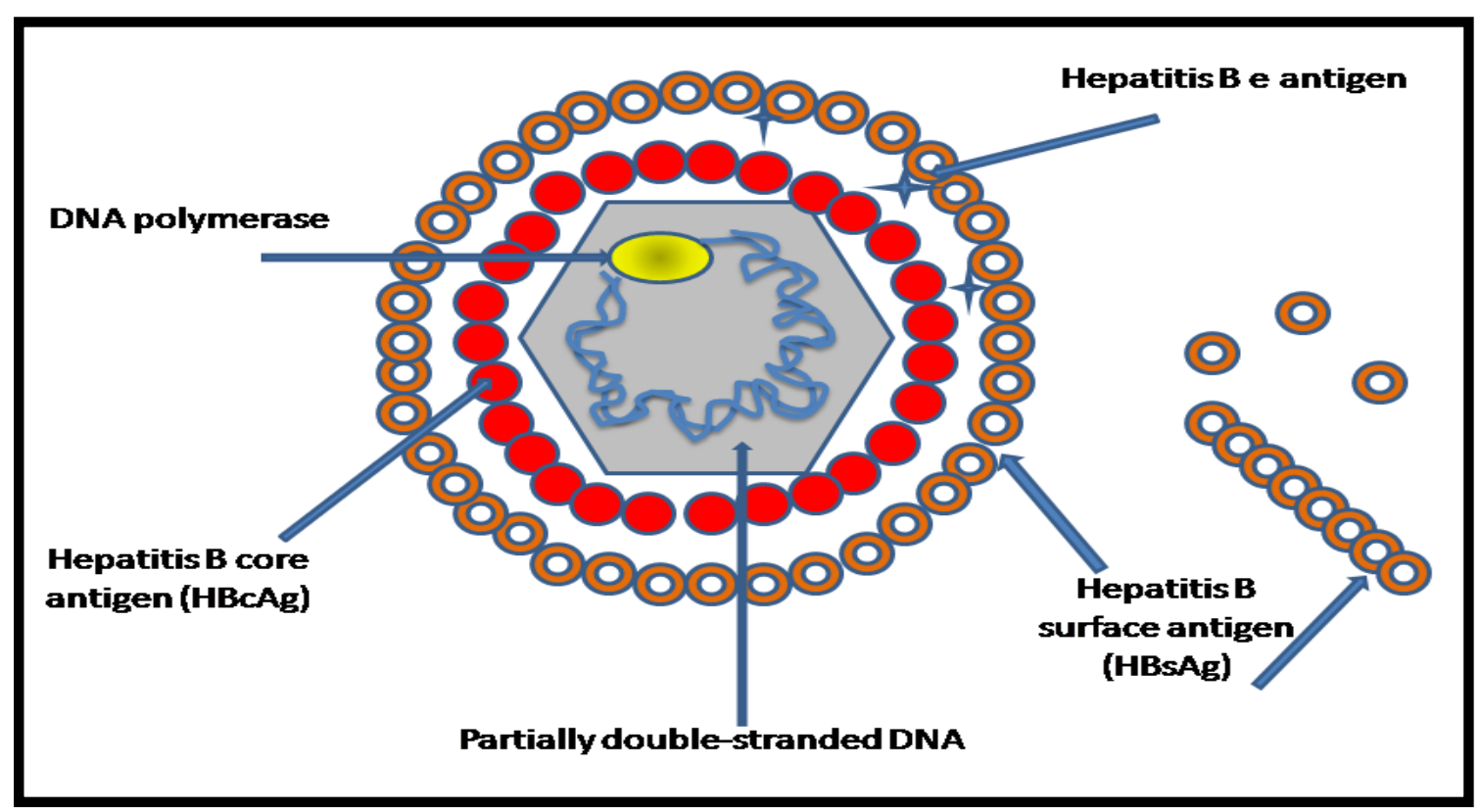

Fig. (2): - A simplified drawing of the HBV particle and surface antigen [60].

\section{Diagnosis and Criteria of HBV infection}

The diagnosis of hepatitis is made by biochemical assessment of liver function, initial laboratory evaluation should include total and direct bilirubin, alanine aminotransferase (ALT) and aspartate aminotransferase(AST), alkaline phosphatase (ALP), total protein, albumin, globulin, complete blood count, erythrocyte sedimentation rate (ESR) and coagulation profile [23, 45]. Viral hepatitis $\mathrm{B}$ diagnosis is confirmed by detection of specific markers (antigens and/or antibodies) in the serum of infected patients $[24,14]$.

Aims of the study: The present study aimed to fulfill and to determine the best marker to be used as predictive parameter in the prognosis and disease progression in Iraqi hepatitis patients.

\section{Methodology}

\section{Subject}

Patients groups include the following:

Chronic hepatitis B patient's groups

A total of (200) patients with CHB who were admitted to Hepatology and Gastroenterology Teaching Hospital in Baghdad, aged from 20-65 years by mean \pm SD 31y. The patients were suffering from different clinical symptoms with previous risk factors for transmission of HBV infection. 


\section{Control groups}

A- A total of 100 healthy HBs Ag carriers were discovered accidentally through attending blood bank for donation of blood, aged from 18-52 years by mean \pm SD, 45.06y.

\section{Patients and carriers blood samples were submitted for the following:}

\section{Biochemical tests.}

\section{Total serum bilirubin (TSB) determination:}

The estimation of TSB was done by using the diazo reagent. Sulfanilic acid reacts with sodium nitrite to form diazotized sulfanilic acid, in the presence of Dimethyl sulfoxide, total bilirubin reacts with diazotized sulfanilic acid to form azobilirubin while in the absence of Dimethyl sulfoxide, only direct bilirubin reacts with diazotized sulfanilic acid to form azobilirubin color formation was measured by a spectrophotometer (wave length $555 \mathrm{~nm}$ ) [21].

\section{Aminotransferases determination:}

According to the method of Lee, et al., [33], for colorimetric determination of serum alanine aminotransferase $(\mathrm{ALT}=\mathrm{GPT})$ and aspartate aminotransferase $(\mathrm{AST}=\mathrm{GOT})$.

\section{Principle of ALT:}

Glutamic Pyruvic Transaminase(GPT) was measured by monitoring the concentration of pyruvate hydrazone formed with 2,4dinitrophenyl-hydrazine; absorbance was measured by spectrophotometer (wave length $540 \mathrm{~nm}$ ) [48, 13].

\section{Principle of AST:}

Glutamic Oxaloacetic Transaminase was measured by monitoring the concentration of oxaloacetate hydrazone formed with 2,4dinitrophenyl-hydrazine, absorbance was measured by spectrophotometer (wave length $540 \mathrm{~nm}$ ) [48, 41].

\section{Alkaline phosphatase determination (ALP)}

According to the method of Turan et al., [55], for the determination of plasma phosphatase enzymes.

\section{Principle:}

Colorimetric determination of alkaline phosphatase activity according to the following reaction:

$$
\begin{gathered}
\text { ALP } \\
\text { Phenylphosphate } \rightarrow \quad \text { Phenol }+ \text { phosphate }
\end{gathered}
$$

\section{PH 10}

The liberated phenol is measured, in the presence of 4-aminoantipyrine and potassium ferricyanide, by spectrophotometer (wave length $510 \mathrm{~nm}$ ). 
The procedure of determination of serum protein was according to Coeurdacier et al., [15].

\section{Principle:}

Cupric ions, in an alkaline medium, interact with protein peptide bonds resulting in the formation of a colored complex which was measured by spectrophotometer of wave length $546 \mathrm{~nm}[48,7$.

\section{Serum Albumin}

According to Metz and Schutre [40]. The albumin specifically binds to green bromocresol (GBC) with acid $\mathrm{pH}$, the green color given by GBC was proportional to the albumin contained in the sample. Absorbance was read at $650 \mathrm{~nm}$ wavelength of spectrophotometer $[48,32,17]$

\section{Serum Globulin}

Determination of globulin was calculated from the difference between total protein and albumin according to the Buzanovskii, [7]

\section{Results}

\section{Biochemical parameters.}

The outcome of biochemical tests indicates that the ALP, GPT, GOT and TSB are higher in CHB

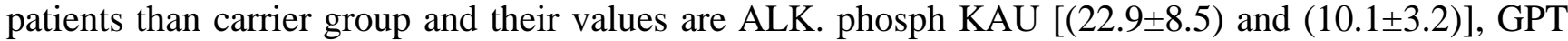

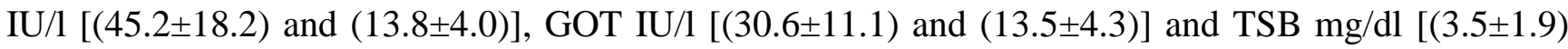
and $(0.9 \pm 0.3)]$ respectively with highly significant difference $(\mathrm{P}<0.001)$. Furthermore, the estimation of serum protein profile can provide helpful clues to diagnosis, hence the total protein, serum albumin and serum globulin give the contradict value. There has been an increase in mean level of protein profiles of carrier group in comparison with chronic group with highly significant difference $(\mathrm{P}<0.001)$, as mention in Table (1) 
Table 1: The comparison between chronic hepatitis B patients and carrier group according to biochemical parameters.

\begin{tabular}{|c|c|c|c|c|c|c|}
\hline \multicolumn{2}{|l|}{$\begin{array}{l}\text { Biochemical } \\
\text { Parameters }\end{array}$} & \multirow{2}{*}{$\begin{array}{l}\text { Number } \\
200\end{array}$} & \multirow{2}{*}{$\begin{aligned} \text { mean } \\
10.12\end{aligned}$} & \multirow{2}{*}{$\begin{array}{ll}\text { SD } & \\
3.29\end{array}$} & \multirow{2}{*}{$\begin{array}{l}\text { P-Value } \\
0.00\end{array}$} & \multirow{2}{*}{$\begin{array}{l}\text { Sig } \\
\text { HS }\end{array}$} \\
\hline ALK.phosph & $\mathrm{CHV}$ & & & & & \\
\hline & $\mathrm{HBV}$ & 100 & 22.96 & 8.51 & & \\
\hline & Total & 300 & & & & \\
\hline \multirow[t]{3}{*}{ GPT } & $\mathrm{CHV}$ & 200 & 13.86 & 4.01 & 0.00 & HS \\
\hline & HBV & 100 & 45.28 & 18.23 & & \\
\hline & Total & 300 & & & & \\
\hline \multirow[t]{3}{*}{ GOT } & $\mathrm{CHV}$ & 200 & 13.52 & 4.32 & 0.00 & HS \\
\hline & $\mathrm{HBV}$ & 100 & 30.62 & 11.1 & & \\
\hline & Total & 300 & & & & \\
\hline \multirow[t]{3}{*}{ TSB } & $\mathrm{CHV}$ & 200 & 0.914 & 367 & 0.00 & HS \\
\hline & $\mathrm{HBV}$ & 100 & 3.586 & 1.915 & & \\
\hline & Total & 300 & & & & \\
\hline \multirow[t]{3}{*}{ globulin } & $\mathrm{CHV}$ & 200 & 3.024 & 0.679 & 0.00 & HS \\
\hline & HBV & 100 & 2.586 & 0.737 & & \\
\hline & Total & 300 & & & & \\
\hline \multirow[t]{3}{*}{ albumin } & $\mathrm{CHV}$ & 200 & 3.826 & 511 & 0.00 & HS \\
\hline & $\mathrm{HBV}$ & 100 & 3.422 & 516 & & \\
\hline & Total & 300 & & & & \\
\hline \multirow[t]{3}{*}{ Total protein } & $\mathrm{CHV}$ & 200 & 6.85 & 787 & 0.00 & HS \\
\hline & $\mathrm{HBV}$ & 100 & 6.026 & 1.128 & & \\
\hline & Total & 300 & & & & \\
\hline
\end{tabular}

Note: - ALP: Alkaline Phosphatase, GPT: Glutamic Pyruvic Transaminase, GOT: Glutamic Oxaloacetic Transaminase and TSB: Total Serum Bilirubin

Normal value: ALK. phosph: 3-13 king Armstrong unit. GPT: up to $13 \mathrm{u} / \mathrm{l}$., GOT: up to $15 \mathrm{u} / \mathrm{l}$. TSB: up to 1.0 $\mathrm{mg} / \mathrm{dl}$. Total protein: $6.5-8.5 \mathrm{~g} / \mathrm{dl}$. Albumin: $3.8-5.5 \mathrm{~g} / \mathrm{dl}$. Globulin: $2.9-3.6 \mathrm{~g} / \mathrm{dl}$ 


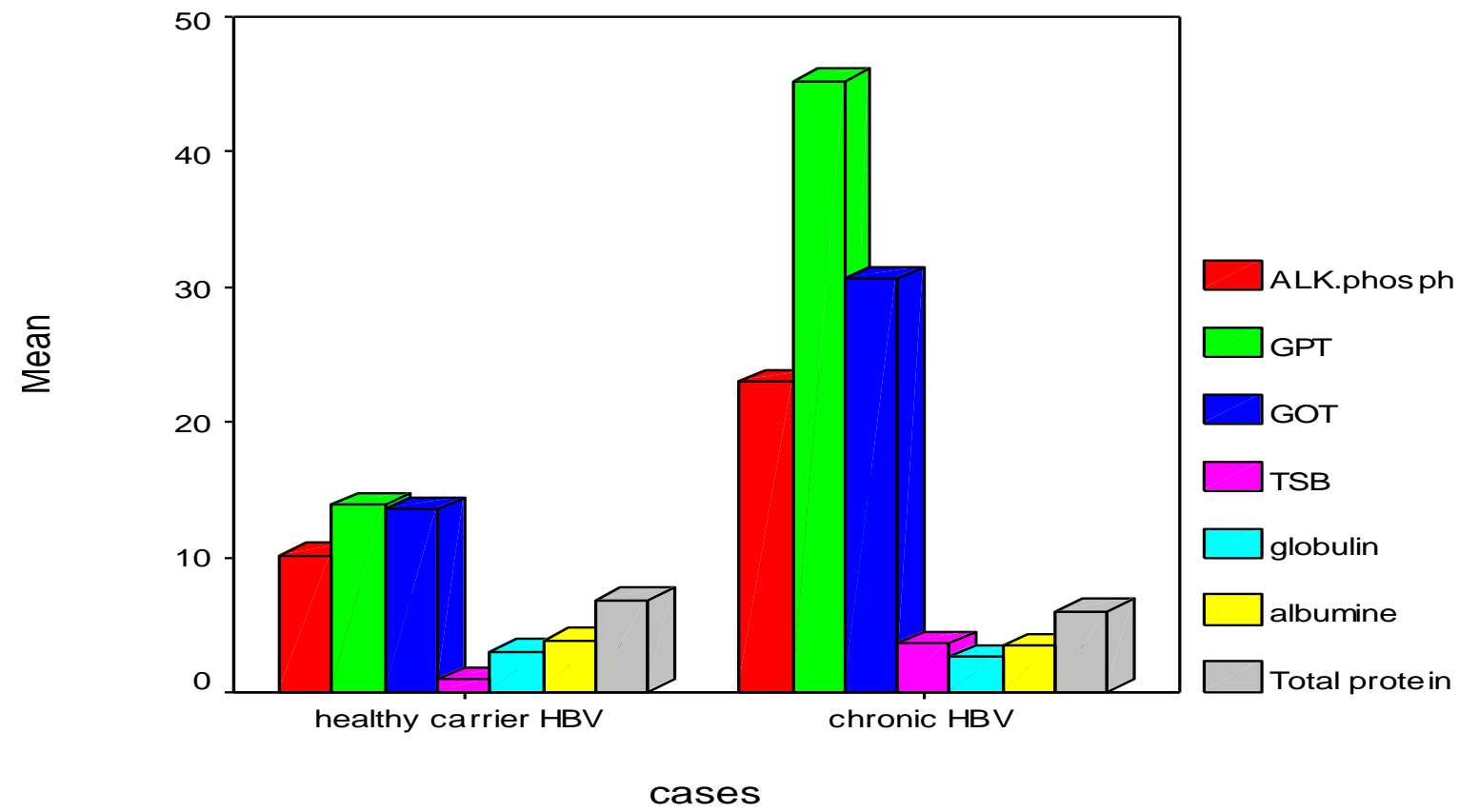

Fig. 3: The relationship between chronic hepatitis B patients and carrier group according to biochemical Parameters

\section{Discussion}

Chronic hepatitis B infection is a common disease wide world, 5\% of the world's population are chronic carriers $[3,61]$, Chronic hepatitis B also believed to be common in Iraq as well as in many other developing countries [43, 42,46,54,31].

This investigation covers a wide range of parameters including virological ,immunogenetics and molecular that may have a possible relationship with infection and investigation was done on 200 patients with $\mathrm{CHB}$ infection and 100 individuals with $\mathrm{HBV}$ carrier. In fact, age at hepatitis B infection seemed to be the most influencing factor in prognosis, the results of this study indicated that the mean age for chronic patients was 45.06y and for carrier group was 35.1y. These results coincide with the previous studies done in Iraq as [2] who establish that 45y was the mean age for CHB patients and [1] reported that the mean age was $38 \mathrm{y}$ for carrier group, also on other hand Dienstag and Rayan in [16] registered that the mean age for carrier and chronic groups was $37 \mathrm{y}$ and $42.6 \mathrm{y}$ respectively. The mean age group affected of CHB patients was higher than the mean age of carrier group which might be due to early exposure to HBV $[16,37]$. 
This work is conducted to figure out any possible relationship between some biochemical parameters and chronic hepatitis. Liver function tests are useful in diagnosis, evaluating severity, monitoring therapy and assessing the prognosis of liver disease and dysfunction. The outcome of biochemical tests which demonstrated in fig. (3), indicates that the ALP, GPT, GOT and TSB are higher in chronic patients than carrier group as also its shown in table (1). The increase of liver enzymes strongly suggests hepatocellular injury [4], beside that the level of ALP, GPT, GOT and TSB in carrier group within normal range as compared to reference value of liver function test $[48,30]$.

Regarding the level of protein, albumin and globulin, it is clear that a decrease in concentration of protein profiles in chronic patients than carrier group. The significant decrease of serum proteins profiles will become apparent in severe or long-standing hepatic disease [44, 29]. On other hand albumin is synthesized exclusively by the liver, in some inflammatory condition the release of tumor necrosis factor inhibits albumin synthesis, but induce the synthesis of acute phase response, hypoalbuminemia is multifactorial but in liver disease the hepatic synthesis of albumin is decreased $[36,9]$.

Moreover, Gheorghe et al. [20] found that in young adults, medical procedures such as injections, dental treatment, surgery and acupuncture are important route of HBV transmission.

After all, hepatitis B infection is considered to be one of the important causes of chronic liver disease all over the world. The possible routes of transmission of $\mathrm{HBV}$ is a multifactorial process, some of them are still controversial.

\section{Conclusions}

This paper summarizes assessment biochemical markers of the development of hepatitis B viruses (HBV), in which any possible connection between certain biochemical parameters and chronic hepatitis was identified. Liver function tests are helpful in diagnosing liver disease and dysfunction, assessing severity, tracking treatment, and determining prognosis. According to the findings of biochemical studies, chronic patients have higher levels of ALP, GPT, GOT, and TSB than carriers. The rise in liver enzymes strongly indicates hepatocellular damage, despite the fact that ALP, GPT, GOT, and TSB levels in the carrier group were all within normal parameters as compared to the reference group. Testing liver function in terms of protein level, albumin, and globulin, the concentration of protein profiles in chronic patients is clearly decreasing as compared to the carrier group. In severe or long-lasting liver disease, the significant decreasing profile of serum proteins is evident in some conditions, the release of tumor necrosis factor hampers the synthesis of albumin, however, induce the synthesis of the acute phase response, hypoalbuminemia is multifactorial, while 
the hepatic synthesis of albumin is decreased in liver disease. These findings may cast new light on immune response especially related to deficiencies of liver synthesis of acute-phase proteins and antioxidant enzyme involvement in viral infections and HBV biology. as well as depend on the biochemical marker as predictive criteria in the evaluation of cirrhosis, fibrosis, and later liver cancer, in a recommendation, several promising developments of $\mathrm{HCC}$ risk scores and biomarkers are underway, and they are expected to transform the "one-size-fits-all" strategy and contribute to the substantial improvement of the poor prognosis of HCC patients in the foreseeable future.

\section{References}

[1] Ahmed, A.M . (2006). The effects of precore mutant on the treatment of chronic viral hepatitis B with Interferon Alfa among Iraqi patients. M.Sc thesis. Genetic Engineering and Biotechnology Institute for Post Graduate Studies. University of Baghdad.

[2] Al-Waysi, A. A. (2005). Effectiveness of interferon-alfa and lamivudine 45. drugs in the treatment of chronic viral Hepatitis (B \&C) among Iraqi patients (Doctoral dissertation, Ph. D. thesis. College of Medicine. Baghdad University).

[3] Berenguer, M. and Wright, T.L. (2002). Viral hepatitis. In : Sleisenger and Fordtrans Gastro intestinal and liver disease, Pathophsiology, diagnosis, management. Edited by Feldman, M., Friedman, L.S., and Sleisenger, M.H. vol 3. pp: 1278-1290.

[4] Berenguer, M., \& Wright, T. L. (2002). Sleisenger \& Fordtran's Gastrointestinal and Liver DiseasePathophysiology/Diagnosis/Management, ed.

[5] Block, T. M., Alter, H. J., London, W. T., \& Bray, M. (2016). A historical perspective on the discovery and elucidation of the hepatitis B virus. Antiviral research, 131, 109-123.

[6] Bruss, V. (2004). Envelopment of the hepatitis B virus nucleocapsid. Virus research, 106(2), 199-209.

[7] Buzanovskii, V. A. (2017). Determination of proteins in blood. Part 1: determination of total protein and albumin. Review Journal of Chemistry, 7(1), 79-124.

[8] Carrion, R., Brasky, K., Mansfield, K., Johnson, C., Gonzales, M., Ticer, A., ... \& Patterson, J. (2007). Lassa virus infection in experimentally infected marmosets: liver pathology and immunophenotypic alterations in target tissues. Journal of virology, 81(12), 6482-6490.

[9] Carvalho, J. R., \& Machado, M. V. (2018). New insights about albumin and liver disease. Annals of hepatology, 17(4), 547-560.

[10] Centers for Disease Control and Prevention (CDC. (2001). FDA approval for a combined hepatitis A and B vaccine. MMWR. Morbidity and mortality weekly report, 50(37), 806-807.

[11] Chaitanya, K. V. (2019). Structure and Organization of Virus Genomes. In Genome and Genomics (pp. 130). Springer, Singapore.

[12] Chen, G., Cheung, R., and Tom, J. W. (2017). Hepatitis: sedation and anesthesia implications. Anesthesia progress, 64(2), 106-118. 
[13] Chen, G., Li, Q., Bai, M., \& Chen, Y. (2019). Nitrogen Metabolism in Acorus calamus L. Leaves Induced Changes in Response to Microcystin-LR at Environmentally Relevant Concentrations. Bulletin of environmental contamination and toxicology, 103(2), 280-285.

[14] Chevaliez, S., \& Pawlotsky, J. M. (2018). New virological tools for screening, diagnosis and monitoring of hepatitis B and C in resource-limited settings. Journal of hepatology, 69(4), 916-926.

[15] Coeurdacier, J. L., Dutto, G., Gasset, E., \& Blancheton, J. P. (2011). Is total serum protein a good indicator for welfare in reared sea bass (Dicentrarchus labrax)?. Aquatic Living Resources, 24(2), 121-127.

[16] Dienstag, J.L. and Rayan, D.M. (2004). occupational exposure to HBV in hospital personnel: infection or immunization. Am. J. Epidemiol.; 115(1): 26-39.

[17] Erstad, B. L. (2021). Serum albumin levels: who needs them?. Annals of Pharmacotherapy, 55(6), 798-804.

[18] Ganem, D. and Prince, A.M. (2004). Hepatitis B virus infection-natural history and clinical consequences. N. Engl. J. Med; 350: 1118-1129.

[19] Gao, W., and Hu, J. (2007). Formation of hepatitis B virus covalently closed circular DNA: removal of genome-linked protein. Journal of virology, 81(12), 6164-6174.

[20] Gheorghe, L., Csiki, I. E., Iacob, S., \& Gheorghe, C. (2013). The prevalence and risk factors of hepatitis B virus infection in an adult population in Romania: a nationwide survey. European journal of gastroenterology \& hepatology, 25(1), 56-64.

[21] Greco, C., Iskander, I. F., Akmal, D. M., El Houchi, S. Z., Khairy, D. A., Bedogni, G., ... \& Zabetta, C. C. (2017). Comparison between Bilistick System and transcutaneous bilirubin in assessing total bilirubin serum concentration in jaundiced newborns. Journal of Perinatology, 37(9), 1028-1031.

[22] Hajj Hussein, I., Chams, N., Chams, S., El Sayegh, S., Badran, R., Raad, M., ... \& Jurjus, A. (2015). Vaccines through centuries: major cornerstones of global health. Frontiers in public health, 3, 269.

[23] Hollinger, F. B. and Liang, T. J. (2001). Hepatitis B virus. In: Fields Virology. Knipe DM et al (eds).4th ed. pp 2971-3036. Lippincott Williams and Wilkins, Philadelphia.

[24] Hoofnagle, J.H. and Lindsay, K.L. (2001). Acute viral hepatitis in: Cecil text book of medicine, Bennett and Plum (eds.), 21st ed. vol. 1. P :783-796. W.B. Saunders Company.

[25] Jawetz,A. ;Melnick,S. and Adelberg's,D. (2004). 'Hepatitis viruses' in: Medical Microbiology. Brooks, G.F., Butel, J. S .and Morse, S.A. (eds.). 32 Edition p 535-563, Appleton and Lange. USA.

[27] Jung, M. C., \& Pape, G. R. (2002). Immunology of hepatitis B infection. The Lancet infectious diseases, 2(1), 43-50.

[28] Juszczyk, J. (2000). Clinical course and consequences of hepatitis B infection. Vaccine, 18, S23-S25.

[29] Kannan, R. (2019). The Impact of Thyroid Hormone Therapy on the Changes in Estimated Glomerular Filtration Rate in Chronic Kidney Disease Patients with Subclinical Hypothyroidism (Doctoral dissertation, Madurai Medical College, Madurai).

[30] Kanter, R., Monshouwer, M., Meijer, D. K. F., \& Groothuis, G. M. M. (2002). Precision-cut organ slices as a tool to study toxicity and metabolism of xenobiotics with special reference to non-hepatic tissues. Current drug metabolism, 3(1), 39-59. 
[31] Kar, R. (2019). Hepatic Coagulopathy: Intricacies and Challenges. In Hematopathology (pp. 339-347). Springer, Singapore.

[32] Kunutsor, S. K., Khan, H., \& Laukkanen, J. A. (2015). Serum albumin concentration and incident type 2 diabetes risk: new findings from a population-based cohort study. Diabetologia, 58(5), 961-967.

[33] Lee, T. H., Kim, W. R., Benson, J. T., Therneau, T. M., \& Melton III, L. J. (2008). Serum aminotransferase activity and mortality risk in a United States community. Hepatology, 47(3), 880-887.

[34] Li, Y. W., Yang, F. C., Lu, H. Q., \& Zhang, J. S. (2016). Hepatocellular carcinoma and hepatitis B surface protein. World journal of gastroenterology, 22(6), 1943.

[35] Liang, T. J. (2009). Hepatitis B: the virus and disease. Hepatology, 49(S5), S13-S21.

[36] Lívero, F. A., \& Acco, A. (2016). Molecular basis of alcoholic fatty liver disease: From incidence to treatment. Hepatology Research, 46(1), 111-123.

[37] Mannaa, F. A., and Abdel-Wahhab, K. G. (2016). Physiological potential of cytokines and liver damages. Hepatoma Research, 2, 131-143.

[38] Martin, N. A. (2003). The discovery of viral hepatitis: A military perspective. BMJ Military Health, 149(2), 121-124.

[39] Mast, E. ; Mahoney , F. ; Kane, M. et al . ( 2004 ) . Hepatitis B vaccine. In: Plotkin, S.A. , Orestein, W.A. , eds . Vaccines . Philadephia : Saunder , $299-337$.

[40] Metz, A.and Schutre, A. (1975). Estimation of albumin in blood. Clin. Chem.; 13:423.

[41] Nwachukwu, C. K., Mba, O. J., Aloh, S. G., \& Okoh, P. M. (2020). Hepatoprotective effects of the methanol extracts of the leaves of Napoleonaea imperialis against carbon tetra chloride (CCl4) induced hepatic damage in albino rats. Stem Cells and Regenerative Medicine, 4(1), 1-7.

[42] Omer, A.R. and AL-Salmani,A. (2005). Hepatitis B virus. Health Ministry and WHO J.; 5:27.

[43] Omer, A.R. and Mohammed,D.A. (2001). Hepatitis B virus in Iraq. Bull. End. Dis.;31(1) :38.

[44] Otter, A. (2013). Diagnostic blood biochemistry and haematology in cattle. In Practice, 35(1), 7-16.

[45] Ramaiah, S. K. (2007). A toxicologist guide to the diagnostic interpretation of hepatic biochemical parameters. Food and chemical toxicology, 45(9), 1551-1557.

[46] Razavi-Shearer, D., Gamkrelidze, I., Nguyen, M. H., Chen, D. S., Van Damme, P., Abbas, Z., ... \& Ryder, S. D. (2018). Global prevalence, treatment, and prevention of hepatitis B virus infection in 2016: a modelling study. The lancet Gastroenterology \& hepatology, 3(6), 383-403.

[47] Regev, A., \& Schiff, E. R. (2000). VIRAL HEPATITIS A, B, AND C. Clinics in liver disease, 4(1), 47-71.

[48] Richard, R. (2002). Enzyme analysis. Annals of Clinical Biochemistry, 39: 496-521.

[49] Seitz, S., Habjanič, J., Schütz, A. K., \& Bartenschlager, R. (2020). The Hepatitis B Virus Envelope Proteins: Molecular Gymnastics Throughout the Viral Life Cycle. Annual Review of Virology, 7, 263-288.

[50] Seitz, S., Urban, S., Antoni, C., \& Böttcher, B. (2007). Cryo-electron microscopy of hepatitis B virions reveals variability in envelope capsid interactions. The EMBO journal, 26(18), 4160-4167. 
[51] Somiya, M., Liu, Q., Yoshimoto, N., Iijima, M., Tatematsu, K., Nakai, T., ... \& Kuroda, S. I. (2016). Cellular uptake of hepatitis B virus envelope L particles is independent of sodium taurocholate cotransporting polypeptide, but dependent on heparan sulfate proteoglycan. Virology, 497, 23-32.

[52] Steven, A. C., Conway, J. F., Cheng, N., Watts, N. R., Belnap, D. M., Harris, A., ... and Wingfield, P. T. (2005). Structure, assembly, and antigenicity of hepatitis B virus capsid proteins. Advances in virus research, 64, 125-164.

[53] Sureau, C., \& Salisse, J. (2013). A conformational heparan sulfate binding site essential to infectivity overlaps with the conserved hepatitis B virus a-determinant. Hepatology, 57(3), 985-994.

[54] Tang, L. S., Covert, E., Wilson, E., \& Kottilil, S. (2018). Chronic hepatitis B infection: a review. Jama, 319(17), 1802-1813.

[55] Turan, S., Topcu, B., Gökçe, I., Güran, T., Atay, Z., Omar, A., ... \& Bereket, A. (2011). Serum alkaline phosphatase levels in healthy children and evaluation of alkaline phosphatasez-scores in different types of rickets. Journal of clinical research in pediatric endocrinology, 3(1), 7.

[56] Venkatakrishnan, B., \& Zlotnick, A. (2016). The structural biology of hepatitis B virus: form and function. Annual review of virology, 3, 429-451.

[57] Wang, L., Wang, K., \& Zou, Z. Q. (2015). Crosstalk between innate and adaptive immunity in hepatitis B virus infection. World journal of hepatology, 7(30), 2980.

[58] Wei, Y., Neuveut, C., Tiollais, P., \& Buendia, M. A. (2010). Molecular biology of the hepatitis B virus and role of the $\mathrm{X}$ gene. Pathologie Biologie, 58(4), 267-272.

[59] Whitacre, D. C., Lee, B. O., \& Milich, D. R. (2009). Use of hepadnavirus core proteins as vaccine platforms. Expert review of vaccines, 8(11), 1565-1573.

[60] William, M. (1997). Hepatitis B virus infection. N Engl J Med.; 337(24): 1733- 45.

[61] Wright, T. L. (2006). Introduction to chronic hepatitis B infection. American journal of gastroenterology, 101, S1-S6. 